\title{
On Fourteen Monostiliferous Hoplonemerteans from the Izu Peninsula, Middle Japan
}

AUTHOR(S):

Yamaoka, Teiichi

\section{CITATION:}

Yamaoka, Teiichi. On Fourteen Monostiliferous Hoplonemerteans from the Izu Peninsula, Middle Japan. PUBLICATIONS OF THE SETO MARINE BIOLOGICAL LABORATORY 2005, 40(3-4): 141-158

ISSUE DATE:

2005-12-25

URL:

http://hdl.handle.net/2433/176324

RIGHT: 


\title{
On Fourteen Monostiliferous Hoplonemerteans from the Izu Peninsula, Middle Japan
}

\author{
TEIICHI YAMAOKA
}

Mitsui Institute of Marine Biology²; Izu, Shizuoka Prefecture, Japan

\begin{abstract}
Of the fourteen species dealt with in this paper, two (Amphiporus cervicalis, Nipponnemertes punctatulus) have previously been reported from Japan; three others ( $A$. imparispinosus, N. pulchra, Tetrastemma melanocephalum) are added to the fauna. Four species (Emplectonema mitsuii, Paranemertes katoi, $N$. ogumai, T. roseocephalum) have been discussed by Crandall, Kajihara, Mawatari, and Iwata (2001). Three of the nemerteans (A. cervicalis, A. imparispinosus, $N$, punctatulus) are known to occur in the eastern North Pacific, and two were originally found in Europe. Five species, belonging to the genera Paranemertes, Amphiporus, Nipponnemertes, and Tetrastemma, though long known from the Japanese fauna, have not yet been given specific names.
\end{abstract}

Key words: Nemertea, Monostilifera, Amphiporus, Nipponnemertes, Tetrastemma

\section{Introduction}

In an early study of nemerteans of Japan, Takakura (1898) reported on 20 species, of which 11 were new. His material was collected on the coast of Misaki, Miura Peninsula, middle Japan. In 1939 and 1940, Mr. Teiichi Yamaoka, a researcher at Mitsui Institute of Marine Biology, collected nemerteans at Shimoda, Izu peninsula, $160 \mathrm{~km}$ from Misaki. The present paper is concerned with this material. Of the 14 species found by Yamaoka, four (Emplectonema mitsuii, Paranemertes katoi, Nipponnemertes ogumai, and Tetrastermma roseocephalum) were new; these were dealt with by Crandall, et al. (2001). Five species belonging to the genera Paranemertes, Amphiporus, Nipponnemertes, and Tetrastemma, though long known from the Japanese fauna, have not yet been given specific names. Three previously described species (Amphiporus imparispinosus, N. pulchra, and T. melanocephalum) were newly added to the fauna of Japan; two (A. cervicalis and $N$. punctatula) had previously been reported. Some of the species found by Yamaoka (A. cervicalis, A. imparispinosus, and $N$. punctatula) are known to occur in the eastern North Pacific, as well as in Japan, and two (N. pulchra and T. melanocephalum) were originally found in Europe.

\section{Results}

\section{Taxonomy}

Class Enopla

Order Hoplonemertea

Suborder Monostilifera

Family Emplectonematidae

1. Emplectonema mitsuii Yamaoka*

2. Paranemertes katoi Yamaoka*

3. Paranemertes sp.

Family Amphiporidae

4. Amphiporus cervicalis (Stimpson)

5. Amphiporus imparispinosus Griffin

1 Deceased.

${ }^{2}$ Closed. 


\author{
6. Amphiporus sp. \\ Family Cratenemertidae \\ 7. Nipponnemertes pulchra (Johnston) \\ 8. Nipponnemertes punctatula (Coe) \\ 9. Nipponnemertes ogumai Yamaoka* \\ 10. Nipponnemertes sp. 1 \\ 11. Nipponnemertes sp. 2 \\ Family Tetrastemmatidae \\ 12. Tetrastemma melanocephalum (Johnston) \\ 13. Tetrastemma roseocephalum Yamaoka* \\ 14. Tetrastemma sp.
}

The four species indicated by asterisks were given the Japanese names mitsui-himomushi, katohimomushi, oguma-himomushi, and menoko-himomushi, respectively, in the Revised Edition of the Illustrated Encyclopedia of the Fauna of Japan (Okuda, 1947) and New Illustrated Encyclopedia of the Fauna of Japan (Okuda and Iwata, 1965). These nemerteans were also given brief descriptions. Revised descriptions were given separately in a recent paper by Crandall, Kajihara, Mawatari, and Iwata (2001).

\title{
Description of species
}

\section{Emplectonema mitsuii Yamaoka, 1947}

Emplectonema mitsuii Yamaoka, 1947: p. 349, figs. a-d (in Okuda, 1947); p. 397, Figs. a-d (Okuda and Iwata, 1965); Crandall, Kajihara, Mawatari, and Iwata, 2001: p. 177, 178, pl. 1, figs. 1-4, pl. 2, figs. 16, 16a, b, pl. 3, figs. 19a-d, pl. 4. figs. 23a, b.

Locality

Susaki, Sotoura and Mikimoto Island, near Shimoda.

\section{Paranemertes katoi Yamaoka, 1947}

Paranemertes katoi Yamaoka: p. 385, figs. a-c (in Okuda, 1947); p. 397 figs. a-c (Okuda and Iwata, 1965); Crandall, Kajihara, Mawatari, and Iwata, 2001: p.178, 179, pl.1, figs. 5-7, pl. 2, fig. 15, pl. 3, figs. 20a, b, pl. 4, figs. 26a-c.

Locality

Susaki and Sotoura, near Shimoda.

\section{Paranemertes sp.}

(Pl. 1, fig. 6; Text-fig. 1)

\section{External feature}

The body is $6 \mathrm{~cm}$ in length and $0.7 \mathrm{~mm}$ in width (Pl. 1, fig. 6). There are two pairs of cephalic grooves on the head; the posterior one encircles the head, forming a $\mathrm{V}$ on the dorsal side, and the anterior one is mostly ventrolateral, extending onto the dorsal side for only a short distance (Figs. 1a, b). The color of the body is bright chestnut-brown, but the anterior margin of the head is white, being clearly marked off from the brown region behind it. Two rather large ocelli are found at the tip of the head.

Internal structure

The proboscis is pale rose. The central stylet is $0.096 \mathrm{~mm}$ long and its basis measures $0.08 \mathrm{~mm}$ 


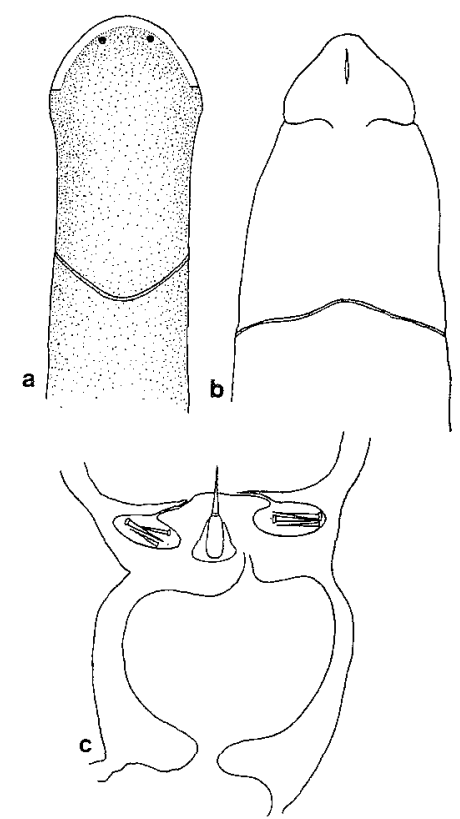

Fig. 1. Paranemertes sp. (a), anterior portion, dorsal view; (b), anterior portion, ventral view; (c), stylet apparatus of proboscis.

long by $0.03 \mathrm{~mm}$ wide. There are 2 lateral pouches of accessory stylets, each containing 3 stylets (Fig. $1 \mathrm{c})$. These stylets are not braided.

\section{Remarks}

The present specimen closely resembles Paranemertes katoi, but differs from it with respect to the following three points: (1) the color of the body is bright chestnut-brown; (2) the stylets have a smooth surface; (3) there are only two ocelli and these are situated near the anterior tip of the head, just as in P. californica.

Locality

One specimen was collected at Itado, near Shimoda, in July, 1939.

\section{Amphiporus cervicalis (Stimpson, 1857)}

(Pl. 1, figs. 2, 4; Text-fig. 2)

Polina cervicalis Stimpson, 1857: p. 165; Gibson, 1995: p. 484.

Amphiporus formidabilis Griffin, 1898: p. 211, figs. 21-22; Coe, 1905: p. 250-252, pl. 17, figs. p. 101-102, text-figs. 13, 15, 23, 54; Iwata, 1952: p.144-146, text-figs. 15, 16; Corrêa, 1964: p. 544-545; Gibson, 1995: p. 283.

Amphiporus cervicalis (Stimpson): Bürger, 1904: p. 39; Iwata, 1954b: p. 25, 26; Gibson \& Crandall, 1989: p. 457; Gibson, 1995: p. 280, 484.

Amphiporus exilis Coe, 1901: p. 54-56, pl. 3, fig. 1, pl. 7, fig. 5, pl. 11, fig. 3; Gibson, 1995: p. 282. 


\section{External features}

The body is slender and somewhat flattened dorsoventrally, being about $10 \mathrm{~cm}$ long by $1 \mathrm{~mm}$ wide (Pl. 1, figs. 2, 4). The head is expanded into the shape of a fan and is wider than the esophageal region; it is also well marked off from the part immediately following by a transverse cephalic groove (Figs. 2a, b). This groove encircles the neck, forming a $\mathrm{V}$ on the dorsal surface, but on the ventral surface it forms a straight transverse line. Two grooves are situated a little anterior to the broadest portion of the head. They do not meet on either the dorsal or ventral surface. The hind end of the body is bluntly pointed. The rhynchodeal opening is a small subterminal pit. There are 50-70 ocelli, and these are arranged in two clusters on each side of the head. An anterior, marginal cluster is situated on both anterolateral borders of the head, and a cerebral cluster is found just in front of the brain and slightly posterior to the marginal groups. The four groups are separated from each other. The color of the body is rose-pink. Microscopic brown spots are sometimes sprinkled all over the surface. The anterior portion of the body is often tinged with vermilion, and the posterior portion is brown, owing to the contents of the intestine. The brain and the lateral nerve cords are distinctly reddish. The proboscis and its sheath are visible through the integument.

\section{Internal structure}

The proboscis sheath extends nearly to the hind end of the body. There are 6,7 or 8 lateral pouches of accessory stylets, and each contains 1, 2 or 3 stylets (Figs. 2c, d). The central stylet is $0.21-0.22 \mathrm{~mm}$ long. Its basis is massive and a little longer than the stylet itself, being $0.22-0.26 \mathrm{~mm}$ long and $0.11-0.13 \mathrm{~mm}$ wide. There are usually 25 proboscis nerves, rarely 24 or 26 . Cephalic glands and submuscular glands are absent. Nephridia extend from a short distance behind the brain to the posterior portion of the esophagus. Throughout the length of the nephridia, numerous efferent ducts
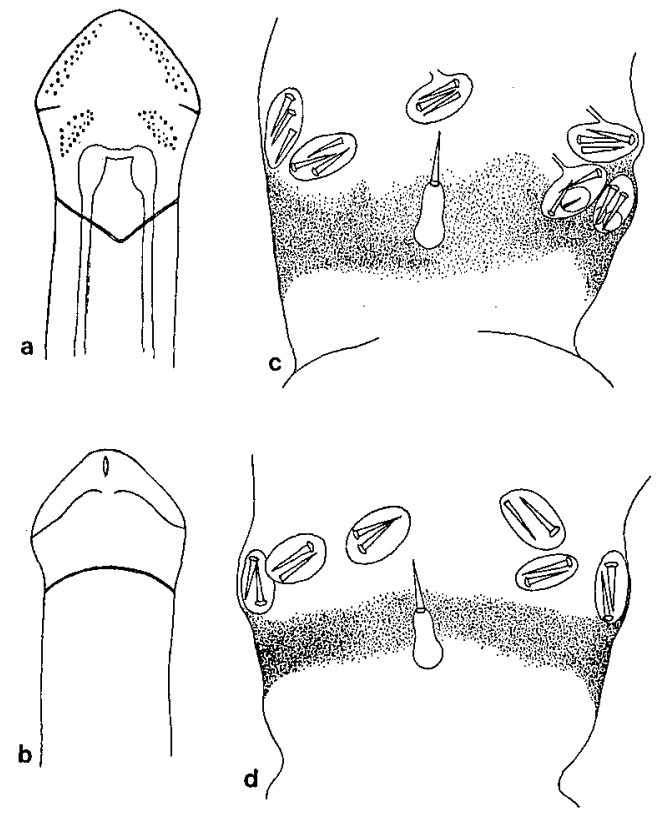

Fig. 2. Amphiporus cervicalis (Stimpson). (a), anterior portion, dorsal view; (b), anterior portion, ventral view; (c) and (d), stylet apparatus of proboscis. 
open externally on the lateroventral surface of the body.

Locality

This species was collected at Susaki, Sotoura and Manazuru, near Shimoda and at Muroran, Hokkaido, in August, 1938.

\section{Amphiporus imparispinosus Griffin, 1898}

(Text-figs. 3, 4a)

Amphiporus imparispinosus Griffin, 1898: p. 210, figs. 19-20; Coe, 1905: p. 247-249, pl. 16, figs. 99, 100, pl. 25, figs. 195-197, text-fig. 53; Corrêa, 1964: p. 542-544; Gibson, 1995: p. 285.

Amphiporus leuciodus Coe, 1901: p. 51-53, pl. 7, fig. 6, text-fig. 13; Punnett, 1901: p. 95; Gibson, 1995: p. 287.

Amphiporus similis Coe, 1905: p. 249, 250, pl. 16, figs. 93, 94, pl. 22, figs. 152, 153; Gibson, 1995: p. 294.

\section{External features}

The body is small and slender, $3-6 \mathrm{~cm}$ long by $0.3-0.5 \mathrm{~mm}$ wide, nearly cylindrical in the esophageal region, and flattened posteriorly. The width of the body is almost uniform throughout its length, and the posterior tip of the body is blunt. The head is slightly marked off from the body. The deep anterior cephalic grooves, just in front of the broadest portion of the head, are more widely separated on the dorsal surface than on the ventral surface, where each has two branches; the posterior groove, which encircles the body behind the head (Figs. 3a, b), forms a V on the dorsal surface and a straight line on the ventral surface. The rhynchodeal opening is a minute, subterminal pit. There are two groups of ocelli on each side of the head. The anterior marginal group consists of about 9 celli, and the irregular posterior group consists of about 8 ocelli lying medial and posterior to the anterior

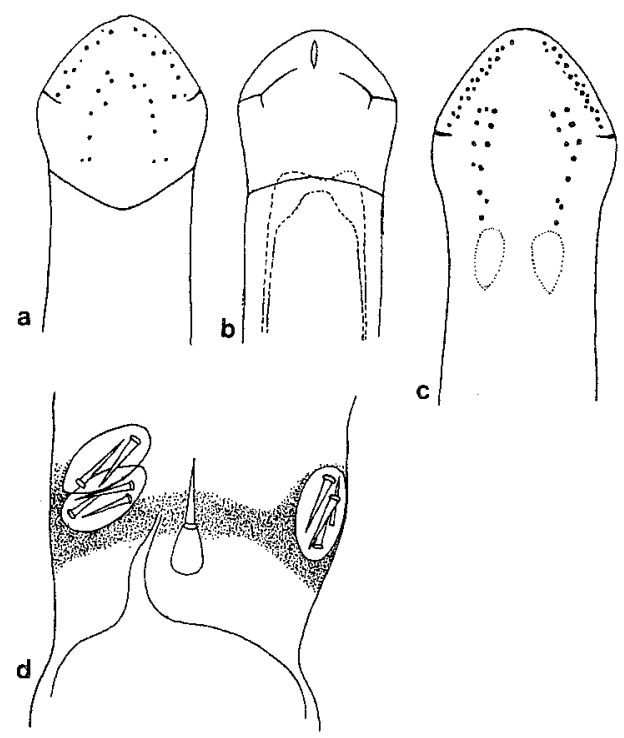

Fig. 3. Amphiporus imparispinosus Griffin, (a), anterior portion, dorsal view; (b), anterior portion, ventral view; (c), anterior portion, dorsal view; (d), stylet apparatus of proboscis. 
one, just in front of the brain (Fig. 3a). The color of the body is white, slightly tinged with yellow. The brain is dark red.

\section{Internal structure}

The proboscis sheath reaches nearly to the posterior end of the body. The central stylet is moderately slender and acutely pointed, and is $0.11 \mathrm{~mm}$ long (Fig. 4a). Its basis is rounded at its larger, posterior end. The length of the basis, $0.11 \mathrm{~mm}$, is equal to that of the central stylet; the width is $0.06 \mathrm{~mm}$. Each of the two pouches of accessory stylets contains two stylets. There are 14 proboscis nerves. Submuscular glands are prominent in front of the brain and beside the brain. The diverticula of the intestinal caecum extend forward to the anterior border of the brain. The cerebral sensory organs are very small and situated a little anterior to the brain. Nephridia extend from slightly behind the brain to the anterior portion of the intestine and beyond several pairs of gonads. Numerous efferent ducts open laterally, passing above the lateral nerve cords. Testes are ripe in summer; they extend from near the posterior end of the body to the level of the anterior portion of the intestine. Their ducts open on the lateral surfaces of the body above the openings of the nephridial ducts.

\section{Remarks}

The Japanese specimens differ from American specimens in having 14 nerves in the proboscis and because the intestinal caeca extend anteriorly as far as the anterior border of the brain. Coe (1901, 1905) reported that the several anterior efferent nephridial ducts open ventrolaterally and others dorsoventrally. In Japanese specimens, however, all the efferent nephridial ducts open on the lateral surface of the body. Two specimens collected at Sotoura (Fig. 3c) lack posterior cephalic grooves. The central stylet is 1.5 times as long as the basis, and the basis is conical in shape. The proboscis has three lateral pouches, each containing 2, 3, or 4 accessory stylets (Fig. 3d). Amphiporus imparispinosus is easily distinguished from $A$. cervicalis, by its body size, coloration, and armature of

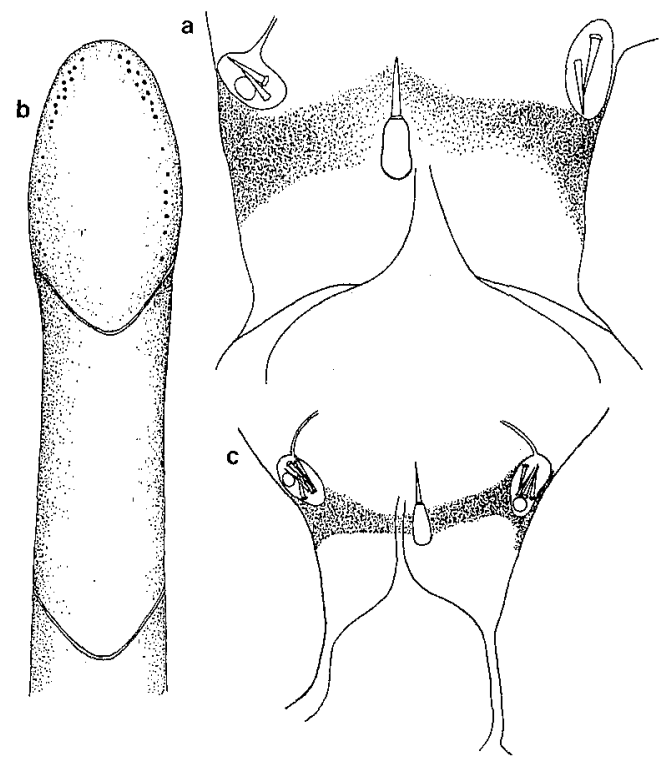

Fig. 4. Amphiporus imparispinosus Griffin. (a), stylet apparatus of proboscis; (b) and (c), Amphiporus sp. (b), anterior portion, dorsal view; (c), stylet apparatus of proboscis. 
the proboscis.

Locality

Three specimens were collected at Sotoura and Mikimoto Island, near Shimoda, in May-July, 1939.

Distribution

West and northwest coasts of America, Alaska, Kamchatka, Bering Strait; Izu, Japan.

\section{Amphiporus sp.}

(Pl. 1, fig. 3; Text-fig. 4b, c)

\section{External features}

The body is small and filiform, cylindrical, $3 \mathrm{~cm}$ long and $0.8 \mathrm{~mm}$ wide in its usual state of extension. It can stretch, however, to a length of $6 \mathrm{~cm}$ (Pl. 1, fig. 3). The head is oval in outline and a little broader than the rest of the body, and the hind end of the body is pointed. The anterior cephalic groove, situated just behind the head, is widely separated from the posterior groove (Fig. 4b). Both grooves form a $\mathrm{V}$ on the dorsal sufface, with the apex pointed backward. Ocelli are arranged in two groups on each lateral margin of the head. The anterior group consists of a cluster of about 10 scattered ocelli, and the posterior group consists of several ocelli arranged in a row. The body is uniformly pinkish red. The proboscis is pale white and the lateral nerves, seen through the body wall, are deep red.

\section{Internal structure}

The proboscis sheath extends to the hind end of the body. The central stylet is $0.1 \mathrm{~mm}$ long and slightly longer than the basis, which is conical in shape and measures $0.09 \mathrm{~mm}$ long by $0.05 \mathrm{~mm}$ wide (Fig. 4c). Each of two lateral pouches contains 4 accessory stylets. The proboscis has 15 nerves. Cephalic glands are absent. The basement membrane is prominent and as thick as the integument. The muscle layers of the body are very thin in the intestinal region and the parenchyma is prominent, occupying a broad space between the body wall and the intestine. The intestinal caeca reach a considerable distance anterior to the brain. The cerebral sensory organs are small and located near the tips of the intestinal caeca. Nephridia extend from slightly posterior to the brain to the hind end of the pylorus. The gonads were not ripe.

Locality

The only specimen was collected at a depth of several meters from a shelly bottom at Susaki, in June, 1939.

\section{Nipponnemertes pulchra (Johnston, 1837)}

(P1. 2, fig. 2; Text-fig. 5a-d)

Nemertes pulchra Johnston, 1837: p. 536, pl. XVII, figs. 6; Gibson, 1995: p. 436, 437.

Amphiporus pusillus Punnett, 1903: p. 29-30, pl. 1, figs. 9-12; Gibson, 1995: p. 292.

Nipponnemertes pulcher (Johnston, 1837): Berg, 1972: p. 211-224, figs. 1-30; Berg, 1985: p. 240; Gibson, 1995: p. 442.

\section{External features}

The body, small and flattened dorso-ventrally, is $13 \mathrm{~mm}$ long by $1.2 \mathrm{~mm}$ wide (Pl. 2, fig. 2). The head, rounded at its apex, is narrower than most of the body (Fig. 5a). The posterior end is bluntly pointed. Ocelli are arranged in two groups on each side of the head. Each anterior marginal group consists of a cluster of numerous ocelli, while each posterior group, near the brain, has only several. 
The dorsal surface of the body is grenadine pink; the head, lateral margins, and ventral surface are white.

\section{Internal structure}

The proboscis sheath reaches nearly to the hind end of the body. There are 12 proboscis nerves in the anterior portion and 13 in the posterior portion. The central stylet is somewhat longer than the basis and each of the two lateral pouches contains 6-8 (rarely 2) accessory stylets (Figs. 5b, c). The basis often has a second stylet embedded in it (Fig. 5d). Cephalic glands, in a few clusters near the anterior tip of the head, are conspicuous. The basement membrane is prominent; in the intestinal region, it is as thick as the muscle layers of the body wall. The circular muscle layer is very thin, consisting of only a few muscle fibers. The parenchymatous tissue is extensive. The intestinal caeca extend forward to near the posterior edge of the brain. The cerebral sensory organs are fairly large and situated lateral to the brain. Their canals open ventrally at the level of the anterior edge of the brain. Nephridia extend anteriorly as far as the middle portion of the brain and posteriorly to the anterior region of the esophagus. Ovaries extend forward to the posterior portion of the esophagus.

\section{Remarks}

The present species is the first record for the fauna of Japan. The Japanese material differs from the Norwegian specimens in the coloration of the body, and also in the relative length of the central stylet and its basis. Yamaoka originally identified the worm as Amphiporus pusillus, but this is synonymous with Nipponnemertes pulchra (Johnston) (Berg, 1972: p. 211-224, figs 1-30; 1985: p. 240). Yamaoka, however, did not mention the existence of the interwoven muscle layers of the proboscis sheath.

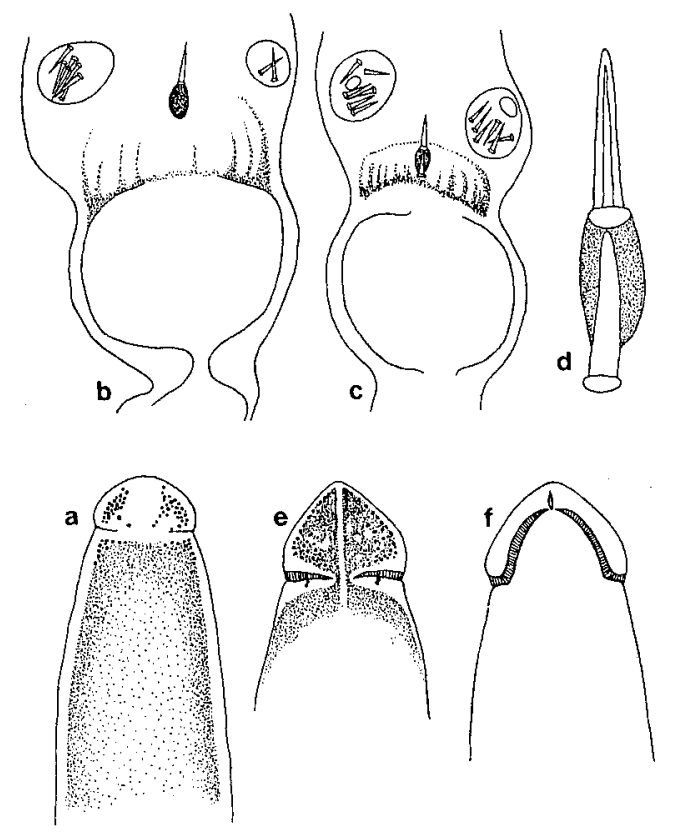

Fig. 5. Nipponnemertes pulchra (Johnston). (a), anterior portion, dorsal view; (b) and (c), stylet apparartus of proboscis; (d), central stylet and basis, with a second stylet; (e) and (f), Nipponnemertes punctatulus (Coe). (e) anterior portion, dorsal view; (f) anterior portion, ventral view. 
Locality

Many specimens were collected from a depth of about 50 meters on a muddy bottom off the coast of Kawazu, near Shimoda, in January, 1940; another specimen was collected at Hashima Island, near Ito, in June, 1939.

Distribution

Bergen, Norway; Hashima and Kawazu, Japan.

\section{Nipponnemertes punctatula (Coe, 1905)}

(Pl. 1, fig. 1; P1. 2, fig. 4; Text-figs. 5e, f, 6a)

Amphiporus punctatulus Coe, 1905: p. 253-259, pl. 21, figs. 129-140, pl. 24, fig. 194; Iwata, 1951: p. 138, fig. 23; Iwata, 1952: p.143-144; Iwata, 1954: p. 39; Iwata, 1954b: p.22-23; Iwata, 1957: p. 21-22; Gibson, 1995: p. 292.

Amphiporus nebulosus Coe, 1901: p. 48-51, text-fig. 12, pl. 4, fig. 1, pl. 8, fig. 6, pl. 11, fig. 1; Takakura, 1933: p. 226; Gibson and Crandall, 1989: p. 466, 467; Gibson, 1995: p. 289, 290.

Nipponnemertes punctatulus Friedrich, 1968: p. 34; Gibson, 1995: p. 442.

\section{External features}

The body is unusually large in comparison with other species of the genus, being commonly about 7-12 cm long by $4-5 \mathrm{~mm}$ wide (Pl. 1, fig. 1; Pl. 2, fig. 4). Still larger specimens, about $23 \mathrm{~cm}$ long and $4-5 \mathrm{~mm}$ wide, were also collected. The body is much flattened dorsoventrally and is well adapted for swimming. The head is somewhat pointed and narrower than the rest of the body, from which it is demarcated by a pair of conspicuous cephalic grooves (Fig. 5e, f). These are transversely ridged in a very characteristic manner. On the dorsal surface, each groove extends toward the midline for only a short distance, but on the ventral surface each is directed forward along the lateral margin of the head and almost meets with its partner just behind the rhynchodeal opening, which is situated subterminally. The hind end of the body is pointed. On the dorsal surface, the body is thickly mottled with confluent blotches and dots of dark brown color, which are conspicuous against the dirty yellow or whitish yellow ground color; on the ventral surface the mottling is nearly absent. The dark dorsal mottling is often so intense as to nearly obscure the paler ground color. Bright vermilion individuals are often found; these have the typical brown dots on the dorsal surface. The margins of the head and cephalic grooves are white; the ventral surface of the head is pure white, without markings. A white median line is especially conspicuous on the anterior portion of the dorsal surface of the head. The brain is visible through the ventral body wall. Ocelli are numerous and fairly large, and are arranged in two groups on both sides of the head. Each anterior group contains about 20 ocelli that form a row along the lateral margin and an irregular cluster just anterior to the cephalic groove. Each posterior group contains 2-3 ocelli and is situated just behind the cephalic groove, far from the anterior group.

\section{Internal structure}

The proboscis is white and its sheath extends nearly to the posterior end of the body. The lateral pouches, two on each side, are provided with $4,5,6$, or 7 accessory stylets. The basis of the central stylet is remarkably short and barrel-shaped, being about a half the length of the stylet itself. It is $0.096 \mathrm{~mm}$ long and $0.08 \mathrm{~mm}$ wide (Fig. 6a). The central stylet is $0.16-0.18 \mathrm{~mm}$ long. There are 14 proboscis nerves. Cephalic glands are prominent in front of the brain. Submuscular glands are also extensively developed on the ventral side of the brain region. The intestinal caeca extend forward only to the posterior end of the nephridia. These are found between the cerebral sensory organs and the middle portion of the esophagus. The dorsoventral muscle fibers are well developed in the intestinal region. The cerebral sensory organ, ventral to the brain, are remarkably large. Where the brain is divided into dorsal and ventral ganglia, the sensory organs enlarge considerably and are closely 
connected with the ventral sides of the dorsal ganglia; they extend backward for a short distance beyond the ganglia. The efferent nephridial ducts originate at the end of the anterior one-third of the nephridial length, and open on the ventral surface.

\section{Remarks}

This nemertean differs slightly from the Californian form of the same species in having (1) a transversely ridgid cephalic groove, (2) a close association of the brain, cerebral sensory organs and nephridia, and (3) weak development of the inner circular muscle layer around the rectum. Amphiporus nebulosus Coe is similar to the present species in external characters and markings of the body, but quite distinct in internal characters. Amphiporus angulatus japonicus resembles the present species in the markings on the head.

Locality

This species was collected at Shimoda in May-August, 1939, Seto and Kushimoto, Kisyu, in April, 1939.

Iwata collected it at Oshoro and Rishiri Island in Hokkaido and at Amakusa, Seto, Shimoda, and Asamushi in Honsyu. Late Sõwa emperor of Japan found it at Hayama.

Distribution

Pacific side of Honsyu and west side of Hokkaido, Japan

\section{Nipponnemertes ogumai (Yamaoka, 1947)}

Amphiporus ogumai Yamaoka, 1947: p. 239, figs. a-c (Okuda, 1947); p. 399, figs, a-c (Okuda and Iwata, 1965).

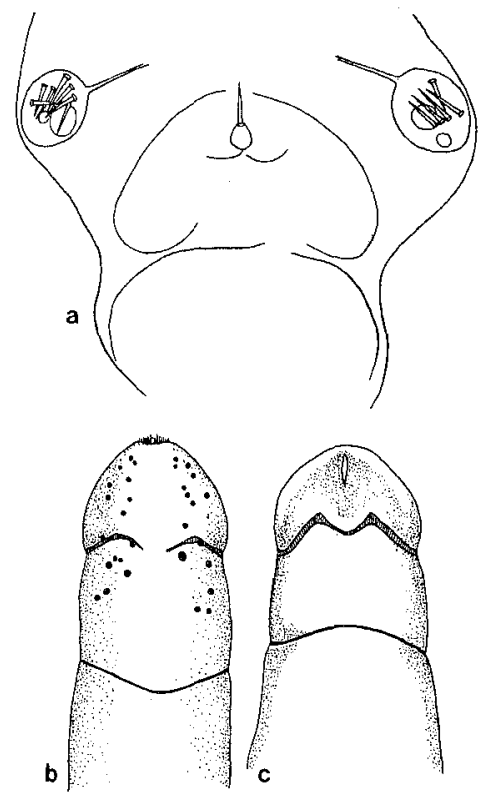

Fig. 6. Nipponnemertes punctatulus (a), stylet apparatus of proboscis; (b) and (c), Nipponnemertes sp. (b) anterior portion, dorsal view; (c) anterior portion, ventral view. 
Nipponnemertes ogumai (Yamaoka, 1947); Crandall, Kajihara, Mawatari, and Iwata, 2001: p. 179,180 , pl. 1, figs. 8-10, pl. 2, fig. 18, pl. 3, figs. 21a, b, pl. 4. fig. 27.

Locality

Itado, near Shimoda.

\section{Nipponnemertes sp. 1}

(Pl. 2, fig. 3; Text-figs. 6b, c, 7)

\section{External features}

The body is cylindrical in cross section, $2.5 \mathrm{~cm}$ long and $0.8 \mathrm{~mm}$ wide (Pl. 2, fig. 3). The head is obtusely pointed and slightly marked off from the esophageal region by a transversely ridged cephalic groove; this is incomplete dorsally, but complete ventrally, forming a somewhat M-shaped configuration (Figs. 6b, c). Another cephalic groove, situated a little behind the anterior one, encircles the body. The posterior end of the body is pointed. About 15 ocelli are irregularly arranged on both lateral margins of the head. The body is yellow tinged with brown; rarely there are small dispersed brown dots. The anterior portion of the body and the ventral surface are somewhat paler. This species can swim effectively.

\section{Internal structure}

The proboscis sheath extends the whole length of the body. Its walls are very thick and composed of interlaced longitudinal and circular muscles, just as is the case in species of Drepanophorus and in Cratenemertes amboinensis, Nipponnemertes drepanophorides, $N$. pulchra, N. pacificus, and $N$. occidentalis (Fig. 7a). The central stylet is $0.08 \mathrm{~mm}$ long and slightly longer than its conical basis, which is $0.06 \mathrm{~mm}$ long and $0.03 \mathrm{~mm}$ wide (Fig. $7 \mathrm{~b}$ ). The proboscis has ten nerves and only one pouch of 6 accessory stylets. Cephalic glands are abundant at the anterior tip of the head. The intestinal

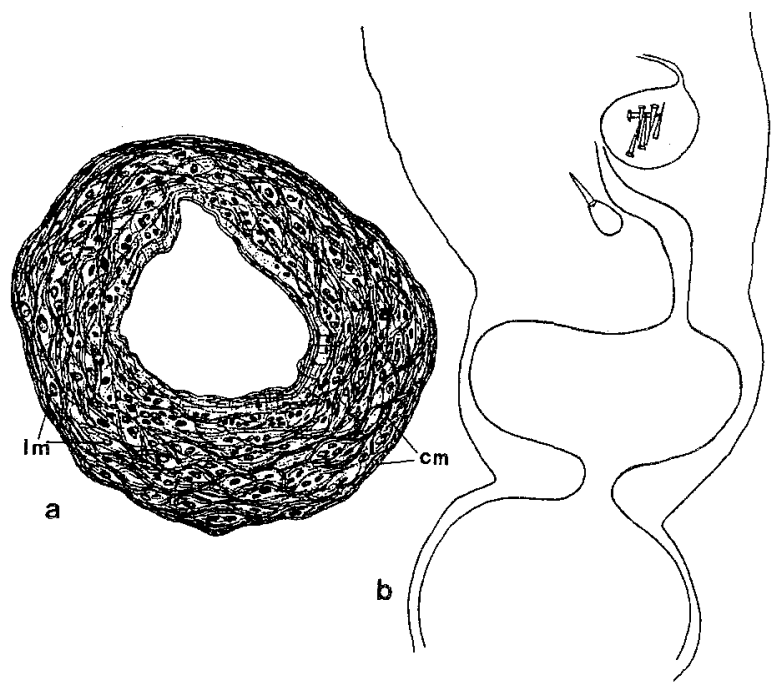

Fig. 7. Nipponnemertes sp. (a), cross section of proboscis sheath, showing interlaced muscle fibers; (b), stylet apparatus of proboscis. $\mathrm{cm}=$ circular muscle fibers; $1 \mathrm{~m}=$ longitudinal muscle fibers. 
caeca extend nearly to the brain. The dorsoventral muscles are fairly well developed in the intestinal region. The cerebral sensory organs extend to the posterior end of the brain; their canals open ventrally a little anterior to the brain. Nephridia extend from the middle portion of the brain to the middle portion of the stomach. The two efferent nephridial ducts, originating near the middle of the nephridia, pass above the lateral nerve cords and open ventrally. The ducts of the gonads open dorsally.

\section{Locality}

Three specimens were found under stones on a beach at Shitaru, near Shimoda, in June; one other specimen was collected at a depth of several meters on a shelly bottom at Susaki in July, 1939.

\section{Nipponnemertes sp. 2}

(Text-fig. 8)

External features

The body is extremely small, 10-12 mm long and $0.7 \mathrm{~mm}$ wide, and flattened dorsoventrally. Both ends are bluntly pointed and the head is narrower than the intestinal region. A cephalic groove, on the ventral surface near the posterior end of the head, forms a nearly M-shaped configuration (Fig. $8 \mathrm{a}-\mathrm{c})$. Another groove, considerably farther posterior, encircles the esophageal region. Numerous ocelli are arranged irregularly along the lateral margins of the head. The rhynchodeal opening is a minute subterminal pit. The color of the body is pure white, yellowish white, or yellow with scattered, extremely small brown patches.

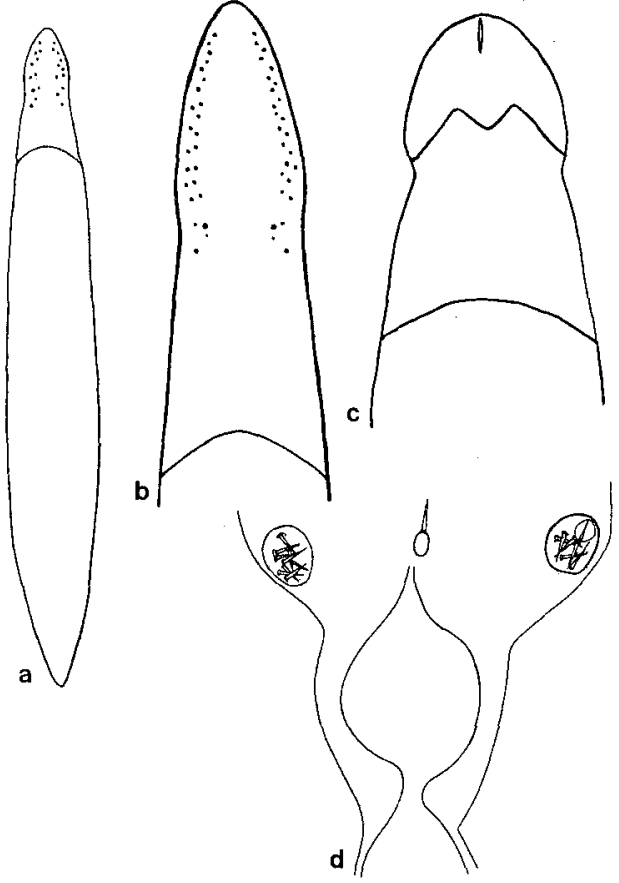

Fig. 8. Nipponnemertes sp. (a), entire animal, dorsal viewe; (b), anterior portion, dorsal view; (c), anterior portion, ventral view; (d), stylet apparatus of proboscis. 
Internal structure

The proboscis sheath extends nearly to the hind end of the body. The central stylet is $0.056 \mathrm{~mm}$ long and a little longer than the basis, which is barrel-shaped and $0.045 \mathrm{~mm}$ long by $0.032 \mathrm{~mm}$ wide (Fig. 8d). The proboscis has two pouches of accessory stylets; each pouch contains 7 or 9 stylets. There are 10 proboscis nerves. Cephalic glands, surrounding the rhynchodeum, are found at the anterior tip of the head. The intestinal caeca terminate a considerable distance behind the brain. The cerebral sensory organs are large and extend a little behind the brain. They are closely associated anteriorly with the lateral walls of the dorsal ganglia, and posteriorly with the dorsal walls of the ventral ganglia. Just in front of the brain, their canals open into the cephalic grooves of the head. Nephridia extend from the level of the posterior end of the brain to the anterior portion of the esophagus. Their efferent ducts pass above the lateral nerve cords and open on the ventral surface of the body. The ovaries were not ripe in the specimens examined.

Locality

Many specimens were dredged at a depth of several meters at Susaki and Shirahama in July, 1939.

\section{Tetrastemma melanocephalum (Johnston, 1837)}

(Pl. 1, fig. 5; Pl. 2, fig. 5; Text-fig. 9a-c)

Nemertes melanocephala Johnston, 1837: p. 535-536, pl. XVII, figs. 5; Gibson, 1995: p. 434.

Tetrastemma melanocephala (Johnston): McIntosh, 1874: p. 165-166, pl. 2, fig.1; Joubin, 1890:

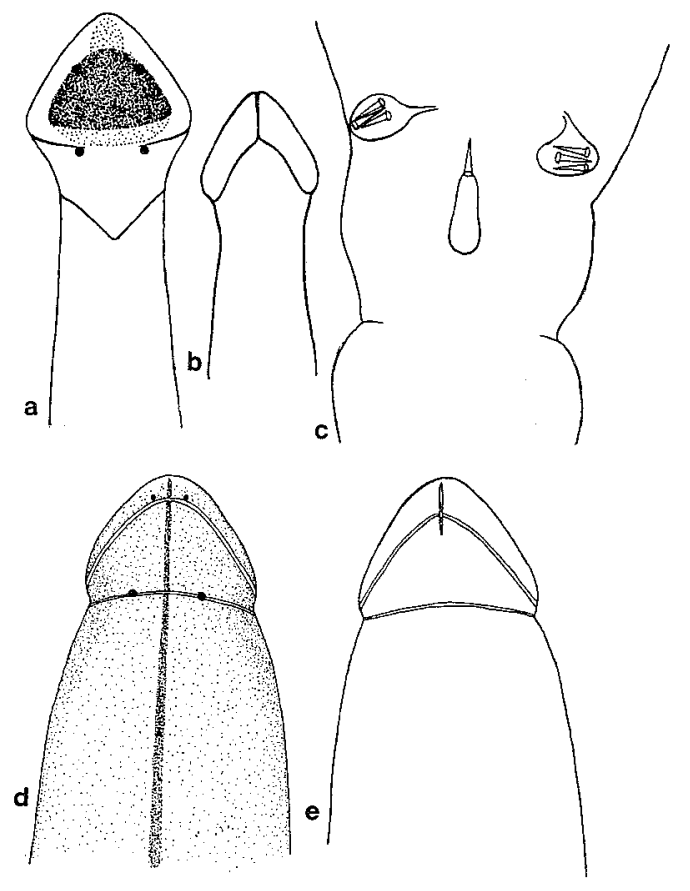

Fig. 9. Tetrastemma melanocephalum (Johnston). (a), anterior portion, dorsal view; (b), anterior portion, ventral view; (c), stylet apparatus of proboscis; (d) and (e), Tetrastemma sp. (d) anterior portion, dorsal view; (e) anterior portion, ventral view. 
p. 579-580; -, 1894: p. 162-164, pl. 3, fig. 65; Bürger, 1895: p. 581-582, pl. 3, figs. 4, 10, pl. 29, figs. 30-31; Bergendal, 1903: p. 118-119; Gibson, 1995: p. 520.

Prostoma melanocephalum (Johnston): Bürger, 1904: p. 56-57; Wijnhoff, 1912: p. 429-430; Friedrich, 1935: p. 339; -, 1936: p. 41; Gibson, 1995: p. 497.

Tetrastemma melanocephalum (Johnston): Kirsteuer, 1963: p. 569-572, figs. 11, 32; Gibson, 1995: p. 520.

\section{External features}

The slender body, $1.5-6 \mathrm{~cm}$ long and $0.3-1 \mathrm{~mm}$ wide when extended, is flattened ventrally and somewhat convex dorsally. The head is arrowhead-shaped in outline and well marked off from the esophageal region, which is slightly narrower. The intestinal region is broader than the esophageal region and gradually tapers to the blunt posterior end of the body. The rhynchodeal opening is a small subterminal pit (Figs. 9a, b). The anterior cephalic grooves, situated near the broadest portion of the head, extend for a short distance toward the midline on the dorsal surface, but on the ventral surface each one runs anteromedially and meets with its partner on the midline. The posterior groove, located in the hind portion of the dorsal side of the head, passes obliquely backward, forming a V; it does not extend to the ventral surface. There are two pairs of ocelli on the head. The anterior pair is near the anterior tip of the head, and the posterior pair is located near the medial ends of the anterior cephalic grooves. The interval between the two ocelli of the anterior pair is a little broader than that separating the posterior pair. The color of the body is usually orange-yellow, sometimes white (Pl. 1, fig. 5). A large and characteristic black or dark brown patch is found on the head (Pl. 2, fig. 5). It is variable in shape, being quadrate or triangular. The anterior border of this patch always covers the anterior ocelli and often extends forward beyond the ocelli. Silver-white areas are found on both anterior and posterior sides of this brown patch. The red brain is seen through the body wall immediately anterior to the V-shaped formation of the posterior cephalic groove.

\section{Internal structure}

The proboscis sheath extends nearly to the posterior end of the body. The armature of the proboscis consists of a short central stylet and two pouches of accessory stylets. The basis of the central stylet is long and stout, constricted near its middle portion and somewhat swollen at the posterior end. It measures $0.14-0.16 \mathrm{~mm}$ long and $0.05-0.06 \mathrm{~mm}$ wide, and is about 1.5 times as long as the central stylet itself, which is about $0.08 \mathrm{~mm}$ long (Fig. 9c). Each lateral pouch contains two or three accessory stylets. There are 11 proboscis nerves. The wall of the proboscis consists of inner circular and outer longitudinal muscle layers. Cephalic glands are fairly prominent at the tip of the head. The intestinal caeca extend forward beyond the ventral commissure of the brain. The cerebral sensory organs are situated in front of the brain and extend backward to the ventral commissure. The nephridia reach anteriorly beyond the ventral commissure. The paired efferent nephridial ducts pass through the body wall just above the lateral nerve cords and open externally on the lateral margins of the body slightly posterior to the brain.

\section{Remarks}

This is the first Japanese record for the species. Worms from Japan are a little smaller than those from Europe, and differ also in having 10 proboscis nerves instead of 11.

Tetrastemma melanocephalum (Johnston, 1837) was redescribed by Kirsteuer (1963).

Locality

The worms are abundant, in March-July, under stones or among the holdfasts of seaweed on beaches near Shimoda. 
Distribution

North Atlantic Ocean, Mediterranean Sea, Black Sea; Izu, Japan.

\section{Tetrastemma roseocephalum Yamaoka, 1947}

Tetrastemma reseocephalum Yamaoka: p. 368, figs. a-c (in Okuda, 1947); Crandall, Kajihara, Mawatari, and Iwata, 2001: p. 180, pl. 1, figs. 11-14, pl. 2, figs. 17, 17a, pl. 3, figs. 22a-d, pl. 4, figs. $24 a, b$.

Locality

Shimoda

\section{Tetrastemma sp.}

(Pl. 2, fig. 1; Text-figs. 9d, e, 10)

External features

The small and stout body, $1 \mathrm{~cm}$ long and $2 \mathrm{~mm}$ wide, is flattened ventrally and slightly convex dorsally. The head is bluntly pointed and well marked off from the esophageal region by a constriction (Figs. 9d, e). The intestinal region is widest in its middle portion, and the posterior end of the body is pointed. The rhynchodeal opening is a small terminal slit. Two cephalic grooves encircle the head; the anterior one runs along the margin of the head on both the dorsal and ventral surfaces, and the posterior one is situated on the constriction. There are two pairs of ocelli; these are embedded deep in the tissue. The smaller anterior pair is situated near the anterior tip of the head, just in front of the anterior cephalic groove, and the larger posterior pair is beneath the posterior cephalic groove. The space between the two ocelli of the anterior pair is narrower than that between the posterior ocelli. The color of the body is reddish brown on the dorsal surface and somewhat paler on the ventral surface (Pl. 2, fig. 1). A dark brown longitudinal line extends the whole length of the body on the dorsal surface. The cephalic grooves are yellow.

\section{Internal structure}

The proboscis is white and has ten nerves. The armature of the proboscis was observed only in sections. The central stylet is only $0.07 \mathrm{~mm}$ long; the basis is much longer, $0.29 \mathrm{~mm}$. Each of the two lateral pouches contains one or two accessory stylets. The proboscis sheath extends nearly to the hind

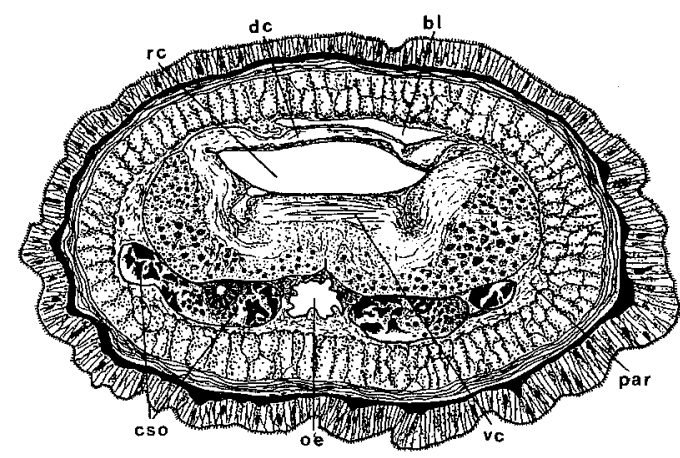

Fig. 10. Tetrastemma sp. Cross section through brain-region. bl = blood lacuna; cso = cerebral sensory organ; $\mathrm{dc}=$ dorsal commissure; oe = esophagus; par = parenchyma; $\mathrm{rc}=$ rhynchocoel; $\mathrm{vc}=$ ventral commissure. 
end of the body. Cephalic glands are poorly developed at the anterior tip of the head. The anterior ends of the intestinal caeca do not reach as far as the brain. The cerebral sensory organs are large, extending backward as far as the posterior portion of the brain (Fig. 10). The cerebral canals lead to the cerebral grooves on the lateral edges of the head. The nephridial canals are large and extend from the level of the middle portion of the brain to the anterior region of the esophagus. Gonads were not found in the material studied.

Locality

The only specimen was found on July 13, 1939, on Laminaria; this was dredged by a towing net at a depth of about 5 fathoms at Shirahama, near Shimoda.

\section{Acknowledgments}

Before his death, Mr. Yamaoka expressed appreciation to the authorities of the Mitsui Institute of Marine Biology for providing facilities for research. He also thanked Prof. Dr. Tohru Uchida for kind guidance during the course of his work.

\section{References}

Berg, G. 1972. Studies on Nipponnemertes Friedrich, 1968 (Nemertini Hoplonemertini). I. Redescription of Nipponnemertes pulcher (Johnston, 1873) with special reference to intraspecific variation of the characters. Zoologica Scripta, 1, 211-225.

Berg, G. 1985. Studies on Nipponnemertes Friedrich (Nemertini, Hoplonemertini). II. Taxonomy of Nipponnemertes pulcher (Johnston) and some other species. Zoologica Scripta, 14, 239-246.

Bergendal, D.1903. Till kännedomen om de nordiska Nemertiner. 4. Förteckning öfver vid Sveriges vestkust iakttagna Nemertiner. Arkiv för Zoologi, 1, 85-156.

Bürger, O., 1895. Die Nemertinen des Golfes von Neapel und der angrenzende Meeres-Abschnitte. Fauna und Flora des Golfes von Neapel, 22, 1-743.

Bürger, O. 1904. Nemertini. Das Tierreich. 20, 1-151.

Coe, W. R., 1901. Papers from the Harriman Alaska Expedition. XX. The nemerteans. Proceedings of the Washington Academy of Sciences, 3, 1-110.

Coe, W. R., 1905. Nemerteans of the west and northwest coasts of America. Bulletin of The Museum of Comparative Zoology at Harvard College, 47, 1-318.

Corrêa, D. D. 1964. Nemerteans from California and Oregon. Proceedings of the California Academy of Sciences, Series 4, 31, 515-558.

Crandall, F. B., Kajihara, H., Mawatari, S. F., and Iwata, F. 2001. The status of four Japanese nemertean species of Yamaoka. Hydrobiologia, 456, 175-185.

Friedrich, H. 1935. Studien zur Morphologie, Systematik und Ökologie der Nemertinen der Kieler Bucht. Archiv für Naturgeschichte, 4, 293-375.

Friedrich, H. 1936. Nemertini. Tierwelt der Nord-und Ostsee. 30, 4d, 1-69.

Friedrich, H. 1968. Sagaminemertes, eine bemerkenswerte neue Gattung der Hoplonemertinen und ihre systematische Stellung. Zoologischer Anzeiger, 180, 33-36.

Gibson, R.1995. Nemertean genera and species of the world: an annotated checklist of original names and description citations, synonyms, current taxonomic status, habitats and recorde $\mathrm{d}$ zoogeographic distribution. Journal of Natural History, 29, 271-562.

Gibson, R. and Crandall, F. B.1989. The genus Amphiporus Ehrenberg (Nemertea, Enopla, Monostiliferoidea). Zoologica Scripta, 18, 453-470.

Griffin, B. B. 1898. Description of some marine nemerteans of Puget Sound and Alaska. Annals of the New York Academy of Sciences, 11, 193-217.

Iwata, F.1951. Nemerteans in the vicinity of Onomichi. Journal of the Faculty of Science, Hokkaido University, Series 6, Zoology, 10, 135-138.

Iwata, F.1952. Nemertini from the coasts of Kyusyu. Journal of the Faculty of Science, Hokkaido University, Series 6, Zoology, 11, 126-148.

Iwata, F.1954a. Some nemerteans from the coasts of the Kii Peninsula. Publications of the Seto Marine Biological 
Laboratory, 4, 33-42.

Iwata, F. 1954b. The fauna of Akkeshi Bay. XX. Nemertini in Hokkaido. Journal of the Faculty of Science, Hokkaido University, Series 6, Zoology, 12, 1-39.

Iwata, F. 1957. Nemerteans from Sagami Bay. Publications from the Akkeshi Marine Biological Station. 7,1-31.

Johnston, G. 1837. Miscellanea Zoologica. II. A description of some planarian worms. Magazine of Zoology and Botany, 1, 529-538.

Joubin, L. 1890. Recherches sur les Turbellariés des côtes de France (Némertes). Archives de Zoologie Expérimentale et Générale, Série 2, 8, 461-602.

Joubin, L. 1894. Les Némertiens. In R. Blanchard and J. de Guerne (eds), Fauna Française (Paris; Société d'Editions Scientifiques), $235 \mathrm{pp}$.

Kirsteuer, E., 1963. Beitrag zur Kenntnis der Systematik und Anatomie der adriatischen Nemertinen (Genera Tetrastemma, Oerstedia und Oerstediella). Zoologische Jahrbücher, Abteilungen für Anatomie und Ontogenie der Tiere, 80, 555-616.

McIntosh, W, C. 1874. A Monograph of the British Annelids. Part 1, The Nemerteans. London: Ray Society, $97-$ 214.

Okuda, S. 1947. Nemertinea. In Revised Edition of Illustrated Encyclopedia of the Fauna of Japan (in Japanese). Tokyo: Hokuryu-kan Press, 239-385.

Okuda, S. and Iwata, F. 1965. Nemertinea. In Yo. K. Okada, S. Uchida and T. Uchida (eds), New Illustrated Encyclopedia of the Fauna of Japan (in Japanese). vol. 1. Tokyo: Hokuryu-kan Press, 388-401.

Punnett, R. C. 1901. On some Arctic nemerteans. Proceedings of the Zoological Society of London, 2, 90-107.

Punnett, R. C. 1903. On the nemerteans of Norway. Bergens Museums Årbog, 2, 1-35.

Stimpson, W.1857. Prodromus descriptionis animalium evertebratorum, quae in ad Oceanum Pacificum Septentrionalem, a Republica Federata missa Cadwaladaro Ringgold et Johanne Rodgers Ducibus, observavit e descripsit. Pars II. Turbellarieorum Nemertineorum. Proceedings of the Academy of Natural Sciences of Philadelphia, 9, 159-165.

Takakura, U. 1898. Classification of Nemertine in the vicinity of Misaki (in Japanese). Zoological Magazine, 10 , 38-44, 116-120, 184-187, 331-337, 424-429.

Takakura, U. 1933. Nemerteans of the northern Kurile Islands (in Japanese). Bulletin of the Biogeographical Society of Japan, 4, 226-227.

Wijnhoff, G. 1912. List of nemerteans collected in the neighbourhood of Plymouth from May-September, 1910. Journal of the Marine Biological Association of the United Kingdom, 9, 407-434.

\section{Addendum}

In 1950, the manuscript written by Mr. Teiichi Yamaoka was turned over to Iwata at the Zoological Institute, Faculty of Science, Hokkaido University, but the type specimens and slides used by Yamaoka were not available. At that time (1950), Iwata did not receive any suggestion or request from his teacher Professor Tohru Uchida as to the publication of this manuscript. The time has come for its revision after Iwata's retirement from Hokkaido University and the Kushiro Public University of Economics in 1988 and 1995, respectively.

Iwata's additions to the manuscript are as follows: (1) revision of the original papers of Yamaoka for modernized style of the taxonomy; (2) change of the title; (3) alteration of generic names and specific names; (4) rearrangement of the species and also revised interpretation of structure; (5) simplification of descriptions of species already well known; (6) rearrangement of plate-and text-figures. (Fumio Iwata; Emeritus Professor, Zoological Institute, Faculty of Science, Hokkaido University, Sapporo 060-0810, Japan, thanks to Prof. Dr. Eugene Kozloff of Friday Harbor Laboratories, University of Washington, Friday Harbor, Washington, USA, who helped by reviewing the manuscript. Finally, the comments and suggestions of Prof. Dr. Yoshihisa Shirayama, Director of Seto Marine Biological Laboratory, Kyoto University and four anonymous reviewers are also appreciated. (Correspondence to Laboratory of Biology, Momijidai, Nishi 5-9-13, Atsubetsu-ku, Sapporo 0040013, Japan; E-mail: fumiwata@d6.dion.ne.jp; Tel \& Fax: +81-011-897-7081) 


\section{Explanation of Plates}

\section{Plate I}

Fig. 1. Nipponnemertes punctatula (Coe). Dorsal view.

Fig. 2. Amphiporus cervicalis (Stimpson). Dorsal view.

Fig. 3. Amphiporus sp. Dorsal view.

Fig. 4. Amphiporus cervicalis (Stimpson). Dorsal view.

Fig. 5. Tetrastemma melanocephalum (Johnston). Dorsal view.

Fig. 6. Paranemertes sp. Dorsal view.

\section{Plate II}

Fig. 1. Tetrastemma sp. Dorsal view.

Fig. 2. Nipponnemertes pulchra (Johnston). Dorsal view.

Fig. 3. Nipponnemertes sp. 1 Dorsal view.

Fig. 4. Nipponnemertes punctatula (Coe). Dorsal view.

Fig. 5. Tetrastemma melanocephalum (Johnston). Dorsal view of anterior portion. 


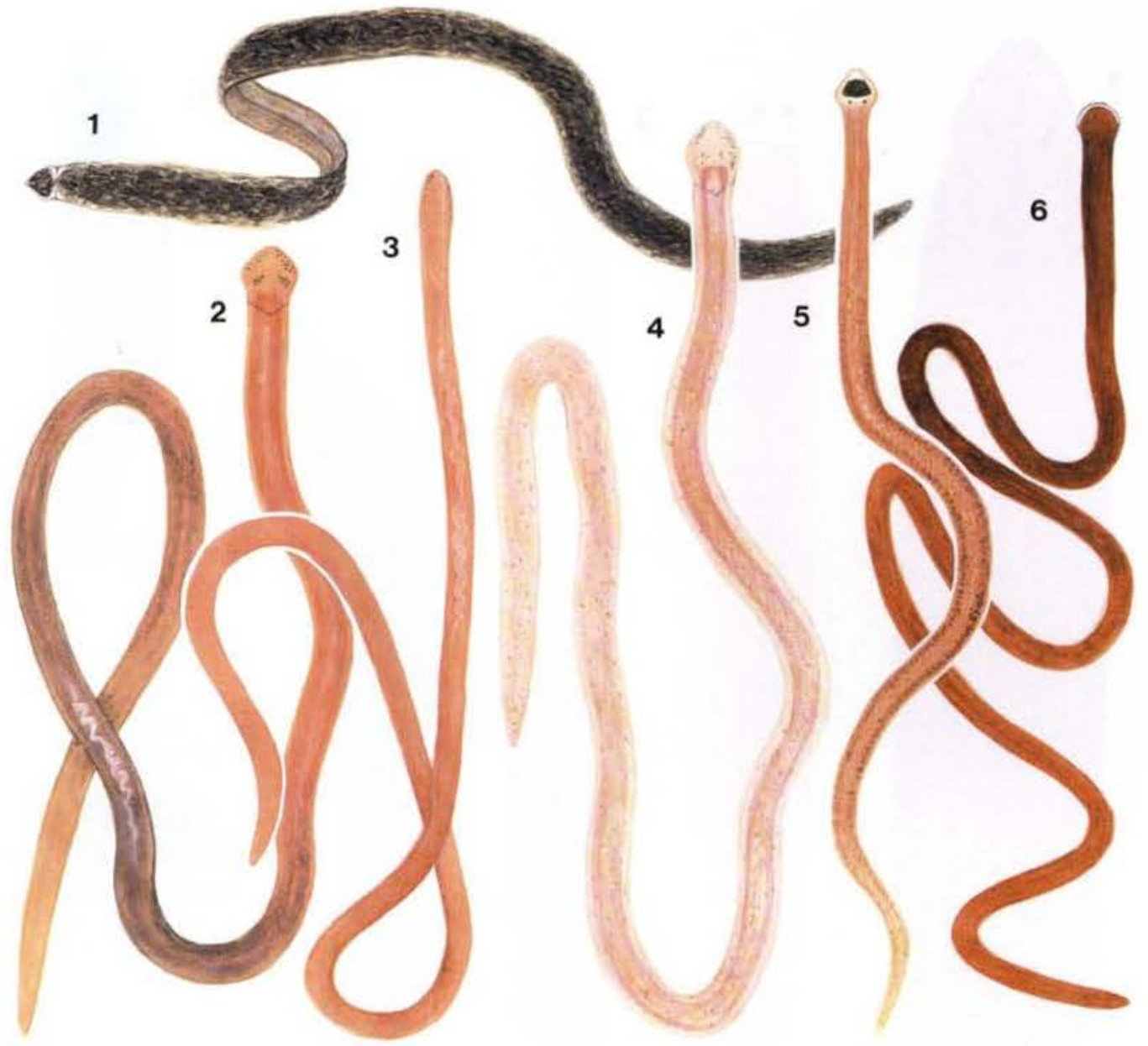



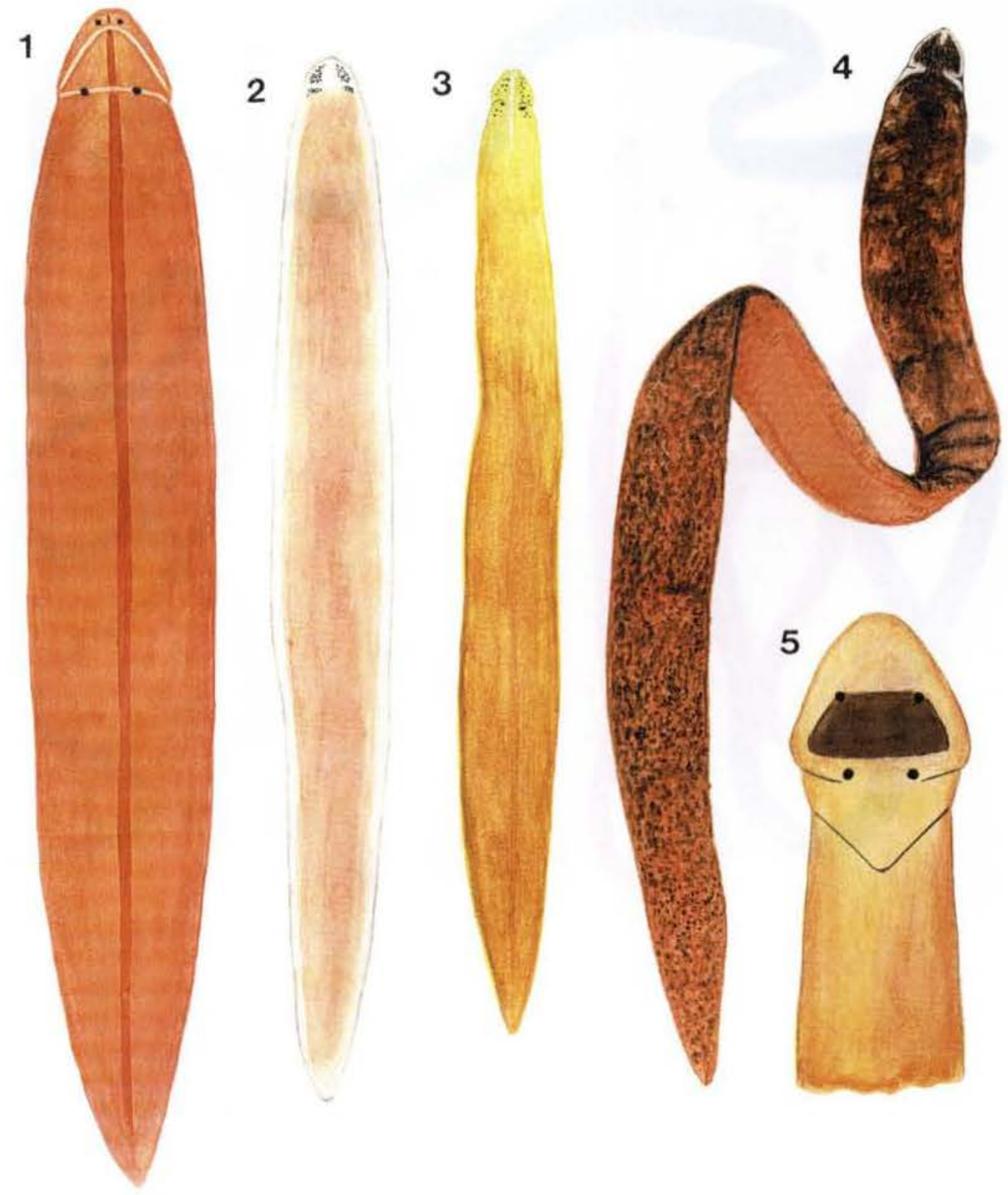